BERTHE MORISOT 



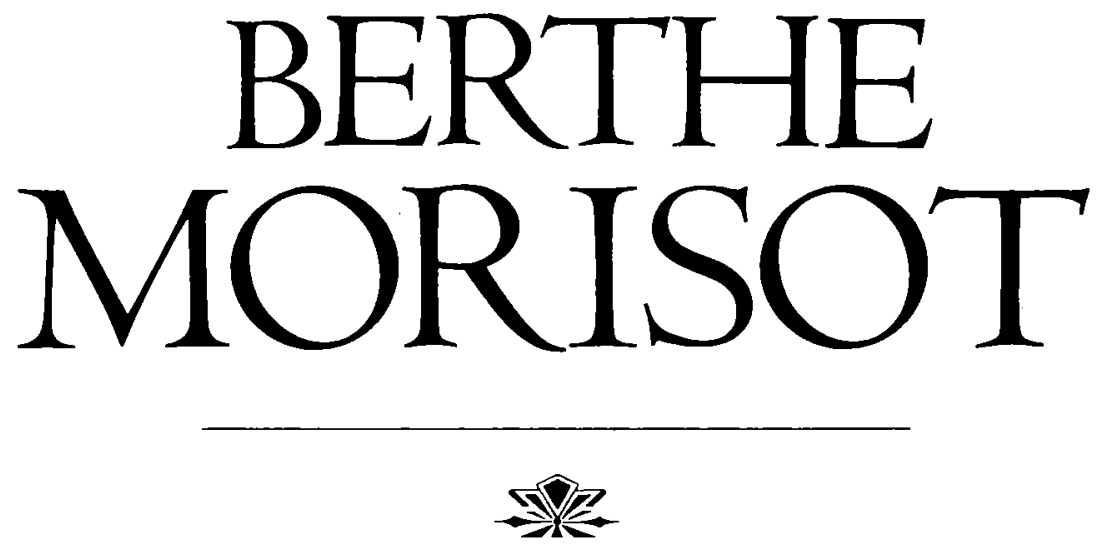

ANNE HIGONNET

UNIVERSITY OF CALIFORNIA PRESS

Berkeley • Los Angeles • London 
University of California Press

Berkeley and Los Angeles, California

University of California Press, Ltd.

London, England

The lines from "Natural Resources" from The Dream of a Common Language, Poems, 1974-1977, by Adrienne Rich, are reprinted with the permission of the author and W. W. Norton \& Company, Inc. Copyright (c) 1978 by W. W. Norton \& Company, Inc.

First California Paperback Printing 1995

BERTHE MORISOT. Copyright (C) 1990 by Anne Higonnet. English translation of Berthe Morisot's letters and notebooks (C) 1990 by Rouart Frères. All rights reserved. Printed in the United States of America. No part of this book may be used or reproduced in any manner whatsoever without written permission except in the case of brief quotations embodied in critical articles and reviews.

\section{Library of Congress Cataloging-in-Publication Data}

Higonnet, Anne, 1959-

Berthe Morisot / Anne Higonnet. - 1st California pbk. print.

p. $\quad \mathrm{cm}$.

Originally published: New York : Harper \& Row, 1990.

Includes bibliographical references and index.

ISBN 0-520-20156-6 (pbk. : alk. paper)

1. Morisot, Berthe, 1841-1895. 2. Artists-France-Biography.

I. Morisot, Berthe, 1841-1895. II. Title.

[ND553.M88H5 1995]

$759.4-\mathrm{dc} 20$

[B]

CIP

$\begin{array}{llllllllll}10 & 9 & 8 & 7 & 6 & 5 & 4 & 3 & 2 & 1\end{array}$

The paper used in this publication meets the minimum requirements of American National Standard for Information Sciences-Permanence of Paper for Printed Library Materials, ANSI Z39.48-1984.@ 
For my grandmother

Thérèse David Higonnet

and to the memory of my grandfather

René Alphonse Higonnet 

The women who first knew themselves miners, are dead. The rainbow flies

like a flying buttress from the walls of cloud, the silver-and-green vein

awaits the battering of the pick the dark lode weeps for light.

My heart is moved by all I cannot save: so much has been destroyed

I have to cast my lot with those who age after age, perversely, with no extraordinary power, reconstitute the world.

-ADRIENNe Rich Natural Resources, 1977 
